\title{
Papilionoideae (Leguminosae) na Mata do Paraíso, Viçosa, Minas Gerais, Brasil: ervas, subarbustos e trepadeiras
}

\author{
Izabella Martins da Costa Rodrigues ${ }^{1,2}$ e Flávia Cristina Pinto Garcia ${ }^{1}$
}

Recebido: 23.06.2008; aceito: 15.10.2008

\begin{abstract}
Papilionoideae (Leguminosae) on Mata do Paraíso, Viçosa, Minas Gerais, Brazil: herbs, shrubs and climbers). This study consists in a floristic survey of Papilionoideae species at shrub and herbaceous layer of Mata do Paraíso, an important fragment of Submontain Semideciduos Seasonal Forest, Viçosa Municipality, "Zona da Mata Mineira" region. The field work was carried out in the studied area, from July/2004 to August/2005, along the trials already set up. Descriptions, illustrations, identification keys to the collected taxa, and comments on the geografic distribution and diagnostic characters were presented.The results of this work were the recognition of 19 taxa belonging to nine genera. From these, Desmodium (six species) and Crotalaria (four species) were the most representative.
\end{abstract}

Key words: Atlantic Forest, Leguminosae, Semideciduos Seasonal Forest

RESUMO - (Papilionoideae (Leguminosae) na Mata do Paraíso, Viçosa, Minas Gerais, Brasil: ervas, subarbustos e trepadeiras). Este estudo consiste em um levantamento florístico das espécies de Papilionoideae componentes do estrato herbáceo-subarbustivo da Mata do Paraíso, um importante fragmento de Floresta Estacional Semidecidual Submontana, em Viçosa, Zona da Mata Mineira. Foram realizadas coletas de material botânico e observações de campo em visitas à área de estudo, no período de julho/2004 a agosto/2005, ao longo de trilhas já estabelecidas. Foram apresentadas descrições, ilustrações e chave para a identificação dos táxons coletados, além de comentários abordando a distribuição geográfica e os caracteres diagnósticos. Foram encontrados 19 táxons distribuídos em nove gêneros. Destes, Desmodium (seis espécies), e Crotalaria (quatro espécies) foram os mais representativos.

Palavras-chave: Floresta Atlântica, Floresta Estacional Semidecidual, Leguminosae

\section{Introdução}

Leguminosae é a terceira maior família entre as angiospermas, abrangendo cerca de 731 gêneros e 19.327 espécies, com distribuição cosmopolita e grande variação de hábitos (Lewis et al. 2005). Segundo Polhill \& Raven (1981), as espécies de Leguminosae são atualmente consideradas um grupo monofilético e estão distribuídas em três subfamílias: Caesalpinioideae, Mimosoideae e Papilionoideae (Chapill 1995, Wojciechowski 2003, Lewis et al. 2005).

Papilionoideae está representada por ervas, subarbustos, arbustos, árvores, trepadeiras e lianas. Apresenta espécies com folhas pinadas ou trifolioladas, nunca bipinadas; inflorescências, geralmente, racemosas ou paniculadas; corola comumente papilionácea de simetria zigomorfa e prefloração imbricada, vexilar; fruto tipo legume, folículo, lomento, sâmara ou drupa. Reúne 28 tribos, 478 gêneros e 13.805 espécies, sendo as espécies herbáceas comuns em regiões temperadas, enquanto que as regiões tropicais contam com maior número de espécies lenhosas (Barroso et al. 1991, Wojciechowski 2003, Lewis et al. 2005). Destaca-se dentre as subfamílias de Leguminosae, por apresentar a maior proporção de espécies capazes de fixar nitrogênio biologicamente através da formação de nódulos em suas raízes, em simbiose com bactérias diazotróficas. Este é um dos fatores que explica a importância de muitas espécies herbáceas de Papilionoideae que são cultivadas como forrageiras em pastagens (Sprent 2001).

Em estudos de composição florística realizados em fragmentos florestais da região de Viçosa, no Domínio da Floresta Atlântica, foi relatada a importância de Leguminosae, em especial de Papilionoideae que, muitas vezes, apresentou a maior riqueza de espécies (Leal Filho 1992, Volpato 1994, Silva et al. 2000, 2003, Meira Neto \& Martins 2000, 2002, Rodrigues \& Garcia, 2007). A maioria desses estudos incluiu somente as espécies arbóreas de Papilionoideae, poucos enfocaram

1. Universidade Federal de Viçosa, Departamento de Biologia Vegetal, Av. P.H. Rolfs s.n., Campus Universitário, 36570-000 Viçosa, Minas Gerais, Brasil

2. Autor para correspondência: izabellamcr@yahoo.com.br 
as espécies que compõem o estrato herbáceo-arbustivo, como o estudo de Meira Neto \& Martins (2000) realizado em Floresta Estacional Semidecidual de Viçosa, onde foram amostradas sete espécies de Papilionoideae, distribuídas em quatro gêneros.

A Mata do Paraíso, situada na Estação de Pesquisa, Treinamento e Educação Ambiental (EPTEA), no município de Viçosa, Zona da Mata Mineira, é um importante fragmento florestal de uma região de alta importância biológica (Drummond et al. 2005). Sua vegetação, classificada como Floresta Estacional Semidecidual Submontana (Veloso et al. 1991), apresenta um histórico de degradação decorrente da retirada de madeira, exploração de pedreira e práticas agrícolas como cultura do café e uso de pastagens $\mathrm{e}$, atualmente, encontra-se em estádio sucessional secundário (Volpato 1994).

O objetivo deste trabalho foi estudar as espécies de Papilionoideae que ocorrem no estrato herbáceosubarbustivo da Estação de Pesquisa, Treinamento e Educação Ambiental (EPTEA), no Município de Viçosa, Zona da Mata mineira. Foram apresentadas chaves para a identificação de gêneros e espécies, descrições morfológicas e ilustrações dos táxons coletados, bem como, comentários abordando aspectos taxonômicos e de distribuição geográfica.

\section{Material e métodos}

A Mata do Paraíso está localizada na Estação de Pesquisa, Treinamento e Educação Ambiental (EPTEA), no Município de Viçosa, Zona da Mata, Minas Gerais, Brasil, nas coordenadas $20^{\circ} 45^{\prime} \mathrm{S}$ e $42^{\circ} 55^{\prime} \mathrm{W}$ (Leal Filho 1992). A EPTEA, administrada pelo Departamento de Engenharia Florestal da Universidade Federal de Viçosa, conta com uma área de 194,36 ha, e está a 689,73 m de altitude (Volpato 1994). O clima, segundo a classificação de Köppen, é do tipo $\mathrm{C}_{\mathrm{wb}}$, tropical de altitude, apresentando verões quentes e chuvosos e invernos frios e secos (Castro 1980). A precipitação média anual varia de 1.500 a $2.000 \mathrm{~mm}$, ocorrendo a maior média entre os meses de setembro e março; a temperatura média oscila de 19 a $22{ }^{\circ} \mathrm{C}$. O período de seca ocorre de abril a agosto (Braz et al. 2000).

A vegetação natural da área, de acordo com a classificação de Veloso et al. (1991), caracteriza-se como Floresta Estacional Semidecidual Submontana, em estádio sucessional secundário, sem registros de incêndio ou extração de madeira desde 1963 (Leal Filho 1992). De acordo com Rizzini (1992) esta vegetação faz parte dos domínios da Floresta Atlântica.
Foram realizadas coletas de ramos férteis e observações ecológicas dos indivíduos de Papilionoideae em visitas mensais à área de estudo, no período de julho a setembro de 2004, e, quinzenais, de outubro de 2004 a julho de 2005. As coletas foram realizadas ao longo de quatro trilhas: a trilha principal, que corta a reserva no sentido norte-sul e seus transectos perpendiculares; o aceiro, que circunda a mata; o "Caminho das Águas" e a "Trilha dos Gigantes", as duas últimas abertas à visitação.

As amostras das plantas foram herborizadas segundo as técnicas descritas por Fidalgo \& Bononi (1989), registradas e incluídas no Herbário VIC, do Departamento de Biologia Vegetal, da Universidade Federal de Viçosa. As flores foram fixadas em álcool $70 \%$ para análise morfológica e ilustração.

A identificação dos indivíduos foi realizada com base na literatura taxonômica dos gêneros e espécies encontrados, por comparação com o acervo do Herbário VIC e confirmação por especialistas. Os nomes dos autores foram abreviados de acordo com Brummitt \& Powell (1992). A classificação genérica está de acordo com Lewis et al. (2005).

A terminologia utilizada para a descrição das estruturas vegetativas e reprodutivas está de acordo com Radford et al. (1974) e, para os frutos, Barroso et al. (1999). Na caracterização dos tipos de hábito foi adotada a terminologia de Guedes-Bruni et al. (2002) com algumas adaptações, sendo consideradas: ervas, plantas não lenhosas com até $50 \mathrm{~cm}$ alt.; subarbustos, plantas eretas com ramificação próxima do chão, cujos ramos são parcialmente lignificados; trepadeiras, plantas com ramos flexíveis não lenhosos que se apoiam em árvores ou arbustos.

As ilustrações das características vegetativas e reprodutivas, importantes para a identificação das espécies, foram confeccionadas com base em material herborizado e/ou fixado em álcool 70\%, com auxílio de estereomicroscópio Olympus.

Após a descrição de cada espécie são apresentados comentários taxonômicos e ecológicos, abordando os caracteres diagnósticos e a distribuição geográfica, obtidos a partir de revisões dos gêneros estudados e do International Legume Database \& Information Service (ILDIS 2007).

\section{Resultados e discussão}

Foram reconhecidos 19 táxons agrupados em nove gêneros, números superiores aos encontrados nos estudos de composição florística para a região de Viçosa (Meira- 
Neto \& Martins 2000). Os gêneros mais representativos foram Desmodium (6 espécies) e Crotalaria (4 espécies), seguido pelos gêneros Centrosema e Rhynchosia com duas espécies cada, enquanto que Aeschynomene, Indigofera, Neonotonia, Vigna e Zornia apresentaram somente uma espécie cada.

Dentre as espécies amostradas apenas duas foram introduzidas, Neonotonia wightii (Wight
\& Arn.) Lackey e Crotalaria lanceolata E. Mey, ambas ocorrendo em áreas perturbadas da EPTEA, às margens do "Caminho das Águas". Estas espécies não foram descritas aqui, no entanto, foram incluídas nas chaves e $C$. lanceolata foi ilustrada (figuras 2F-I) de modo a auxiliar na sua distinção em relação às outras espécies do gênero.

Chave para os gêneros de Papilionoideae na Mata do Paraíso: ervas, subarbustos e trepadeiras

1. Folhas simples, 2-3-folioladas

2. Folhas simples, 2-folioladas

3. Folhas simples; estípulas ausentes; alas internodais presentes; inflorescências em racemo; fruto legume inflado

\section{Crotalaria}

3. Folhas 2-folioladas; estípulas auriculadas; alas internodais ausentes; inflorescências espiciformes; fruto lomento

Zornia

2. Folhas 3-folioladas

4. Subarbustos; fruto lomento ou legume inflado

5. Corola rósea, violácea, azulada ou purpúrea; estames diadelfos; anteras uniformes; fruto lomento Desmodium

5. Corola amarela; estames monadelfos; anteras dimorfas; fruto cilíndrico inflado

Crotalaria

4. Trepadeiras; fruto legume plano

6. Folíolos laterais assimétricos; corola branca, azulada ou amarela; vexilo não giboso

7. Ramo seríceo; cálice 4-laciniado; corola branca; carena espiralada Vigna

7. Ramo hirsuto ou tomentoso; cálice 5-laciniado; corola azulada ou amarela; carena não espiralada

8. Ramo hirsuto; folíolos com face abaxial serícea sem tricomas glandulares; corola azulada; sementes 9 Neonotonia

8. Ramo tomentoso; folíolos com face abaxial vilosa com tricomas glandulares; corola amarela; sementes 2

Rhynchosia

6. Folíolos laterais simétricos; corola violácea; vexilo dorsalmente giboso na base

Centrosema

1. Folhas plurifolioladas

9. Folhas paripinadas; estípulas lanceoladas; fruto lomento Aeschynomene

9. Folhas imparipinadas; estípulas filiformes; fruto legume reflexo Indigofera

Aeschynomene L., Sp. Pl. 2: 713. 1753.

Ervas ou subarbustos. Folhas paripinadas, 5-plurifolioladas, pecioladas; estípulas peltadas, apendiculadas ou não abaixo do ponto de inserção; estipelas ausentes; folíolos alternos ou subopostos. Inflorescências racemosas, terminais ou axilares; brácteas e bractéolas persistentes ou caducas; cálice 5-laciniado ou 2-labiado; corola 5-mera, amarela; estames 10, diadelfos $(5+5)$, anteras uniformes; ovário estipitado; estilete curvo; estigma terminal. Fruto lomento, 1-18-articulado, artículos indeiscentes, planos a convexos.
Aeschynomene elegans Schltdl. \& Cham. var. elegans, Linnaea 5: 583. 1830.

Figura 1A

Subarbusto ereto, 0,4-0,9 m alt.; ramos cilíndricos, vilosos. Folhas 8-12-folioladas; estípulas 3-7 mm compr., lanceoladas; pecíolo 0,2-0,4 cm compr.; raque 1-2 cm compr.; folíolos 0,5-1,1 × 0,2-0,5 $\mathrm{cm}$, oblongos, mucronados, cartáceos, ambas as faces esparso-seríceas, discolores. Inflorescências 1-2-floras, axilares; pedúnculo 0,1-0,8 cm compr.; 

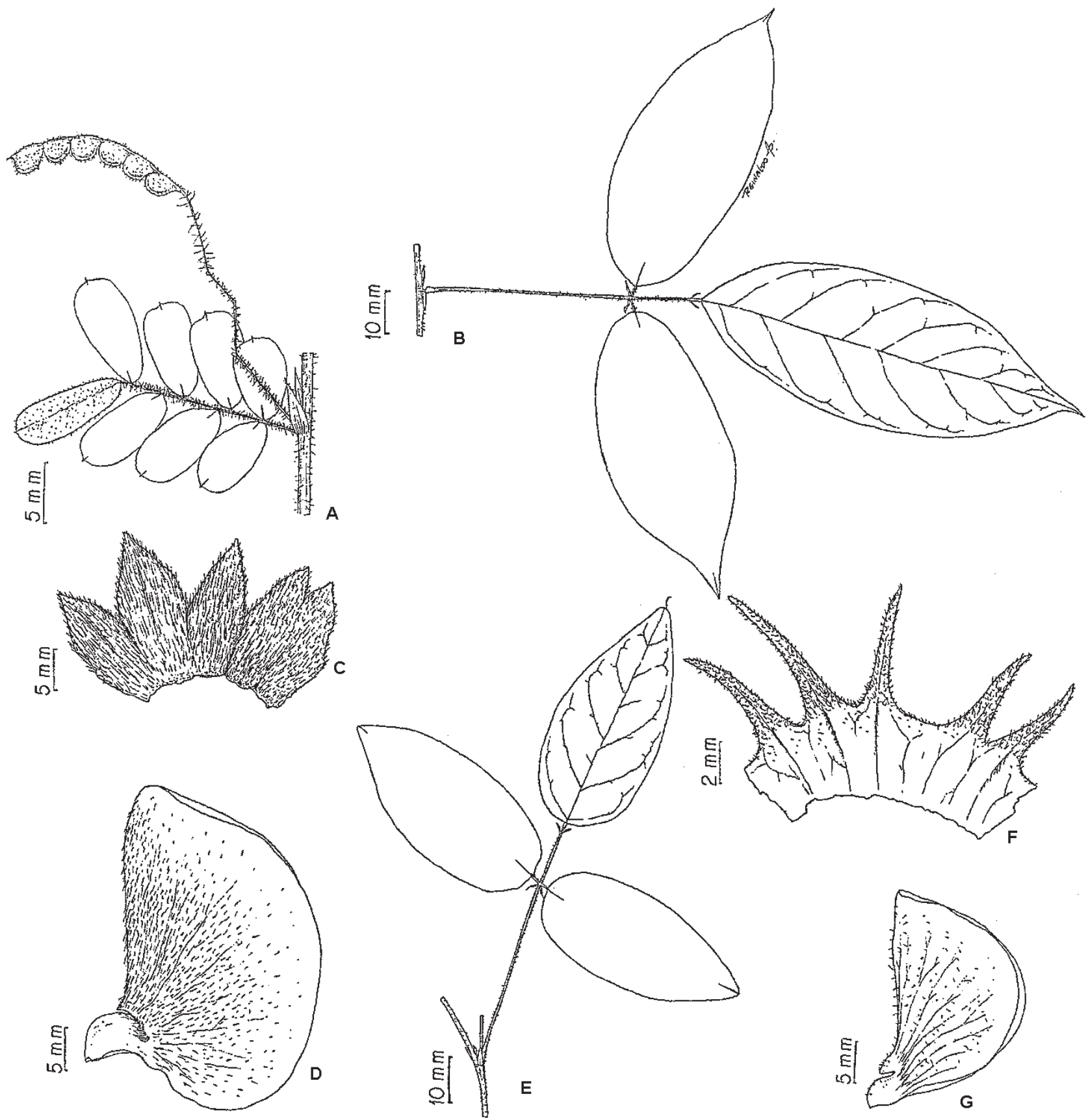

Figura 1. Espécies de Aeschynomene e Centrosema da Mata do Paraíso. A. Aeschynomene elegans var. elegans. A. Ramo com folha e fruto (Rodrigues \& Basílio 30). B-D. Centrosema dasyanthum. B. Folha. C. Cálice. D. Vexilo giboso (Rodrigues \& Ferreira 48). E-G. Centrosema virginianum. E. Folha. F. Cálice. G. Vexilo (Rodrigues \& Ferreira 25). 
raque $0,1-3,8 \mathrm{~cm}$ compr.; cálice 3-3,5 mm compr., externamente seríceo, 5-laciniado, lacínios subiguais entre si, 1-1,5 mm compr.; corola amarela, vexilo 6-7 mm compr., alas 7-8 mm compr., pétalas da carena ca. $8 \mathrm{~mm}$. compr.; estames 6-7 mm compr.; gineceu estipitado; estípite ca. $1 \mathrm{~mm}$ compr.; ovário ca. $4 \mathrm{~mm}$ compr., tomentoso; estilete ca. $3 \mathrm{~mm}$ compr., glabro; estigma truncado. Fruto 2-3 × 0,2 cm, 4-6-articulado, uncinado-pubescente; sementes 4-6, ca. 1 mm compr., orbiculares a reniformes, castanhas.

Material examinado: BRASIL. Minas Gerais: Viçosa, EPTEA, Estrada para o Centro de Educação Ambiental, 26-XI-2004, I.M.C. Rodrigues \& L.A. Basílio 15(VIC); idem, 16-III-2005, I.M.C. Rodrigues \& L.A. Basílio 30 (VIC).

Ocorre do México até o Uruguai e Argentina (Brandão 1992). No Brasil, habita florestas e campos rupestres nos estados de Pernambuco, Bahia, Minas Gerais, Rio de Janeiro, São Paulo, Santa Catarina e Rio Grande do Sul (Rudd 1955, Fernandes 1996).

Na EPTEA ocorre em locais perturbados, nas proximidades do Centro de Educação Ambiental.

Segundo Fernandes (1996) A. elegans apresenta duas variedades: var. elegans e var. robustior. O material examinado foi identificado como pertencente à variedade típica por apresentar os artículos do fruto com ca. 2 mm de diâmetro.

Centrosema (DC.) Benth., Comm. Legum. Gen.: 53. 1837.

Ervas ou trepadeiras. Folhas imparipinadas, 3(-5-7)-folioladas, pecioladas, raque raramente ausente; estípulas persistentes; estipelas setáceas. Inflorescências racemosas, axilares, raramente terminais; brácteas inconspícuas, geminadas; bractéolas adpressas; flores ressupinadas; cálice campanulado, 5-laciniado, lacínios superiores 2, soldados até quase o ápice, lacínios inferiores 3, o mediano semelhante ou maior que os laterais; corola 5-mera, rósea, violácea, azulada ou branca; vexilo orbicular, calcarado ou giboso no dorso; estames 10, diadelfos $(9+1)$, anteras uniformes; ovário séssil a subséssil; estilete curvo; estigma terminal. Fruto legume, linear, plano, elasticamente deiscente, apiculado, com suturas espessadas em ambos os lados.
Chave para as espécies de Centrosema ocorrentes na Mata do Paraíso

1. Folíolos laterais $74-90 \mathrm{~mm}$ compr.; corola roxo-escura; vexilo densamente seríceo externamente; lacínios superiores do cálice unidos até quase o ápice C. dasyanthum

1. Folíolos laterais33-72mm compr.; corola violácea; vexilo glabro externamente; lacínios superiores do cálice separados por sínus campanulado ou oblongo C. virginianum

1. Centrosema dasyanthum Benth., Ann. Nat. Hist. 3: 436.1839.

Figuras 1B-D

Trepadeira; ramos cilíndricos, puberulentos. Folhas 3-folioladas; estípulas 4-6 mm compr., lanceoladas; estipelas 2-5 mm compr., setáceas, caducas; pecíolo 4,2-7,5 cm compr.; raque 1,3-2 cm compr.; folíolos laterais 7,4-9 × 2,8-3,8 cm, elípticos, simétricos, subcartáceos, face adaxial uncinadopubérula, face abaxial pubescente. Inflorescências 2-5floras; pedúnculo 1,6-2,5 cm compr.; raque 0,5-1,4 cm compr.; cálice ca. $15 \mathrm{~mm}$ compr., velutino a tomentoso externamente, lacínios subiguais entre si, largos, os superiores unidos até quase o ápice, os laterais ca. $8 \mathrm{~mm}$ compr., o mediano ca. $10 \mathrm{~mm}$ compr.; corola roxo-escura, vexilo ca. $38 \mathrm{~mm}$ compr., densamente seríceo externamente, alas e pétalas da carena ca. $36 \mathrm{~mm}$ compr., uncinado-pubescente externamente; estames 33-34 mm compr.; ovário ca. 16 mm compr., séssil, puberulento; estilete ca. $20 \mathrm{~mm}$ compr., glabro; estigma laminar, truncado, barbado, emarginado no ápice. Fruto não observado.

Material examinado: BRASIL. Minas GeraIs: Viçosa, EPTEA, Aceiro, 16-V-2005, I.M.C. Rodrigues \& S.C. Ferreira 48 (VIC).

Distribuição restrita à América do Sul e, no Brasil, aos estados de Minas Gerais, Rio de Janeiro e São Paulo, habitando serras, matas ou campos (Barbosa-Fevereiro 1977, ILDIS 2007).

Esta espécie pode ser facilmente reconhecida pelos lacínios do cálice largos, os superiores maiores que o tubo, unidos até quase o ápice, o estigma emarginado no ápice e a cor da corola roxo-escura, esses caracteres permitem diferenciá-la inclusive de $C$. virginanum, a outra espécie do gênero ocorrente na Estação. 
2. Centrosema virginianum (L.) Benth., Comm. Legum. Gen.: 56. 1837.

Figuras 1E-G

Trepadeira; ramos volúveis, estriados, puberulentos. Folhas 3-folioladas; estípulas 3-4 mm compr., triangulares; estipelas 3-6 mm compr., linearlanceoladas; pecíolo 3-5,8 cm compr.; raque 0,7-1,8 cm compr.; folíolos laterais 3,3-7,2 × 1,3-3,5 cm, ovados a elípticos, simétricos, cartáceos, face adaxial glabra com tricomas uncinados ao longo das nervuras, face abaxial pubérula. Inflorescências 1-3-floras; pedúnculo 2-6,1 cm compr.; raque 0,2-1,3 cm compr.; cálice 10-13 mm compr., puberulento externamente, lacínios subiguais entre si, os superiores maiores que o tubo, separados por sínus campanulado ou oblongo e laterais 5-6,5 mm compr., mediano 7-8 mm compr.; corola violácea com guias de néctar brancas, vexilo ca. $27 \mathrm{~mm}$ compr., alas 18-20 mm compr., uncinadopubescente externamente, pétalas da carena 20-22 mm compr., uncinado-pubescente externamente; estames 28-32 mm compr.; ovário 12-16 mm compr., séssil, puberulento; estilete $12-15 \mathrm{~mm}$ compr., puberulento; estigma laminar, truncado, barbado. Fruto 90-127 $\times$ 35-40 mm, reto, glabro; sementes 21-22, ca. $3 \mathrm{~mm}$ compr., negra, orbicular.

Material examinado: BRASIL. Minas Gerais: Viçosa, EPTEA, Estrada para o Centro de Educação Ambiental, 21-II-2005, I.M.C. Rodrigues \& S.C. Ferreira 25 (VIC).

Está distribuída nos Estados Unidos, El Salvador, Peru, Venezuela, Colômbia, Bolívia, Paraguai, Argentina e Brasil, onde ocorre nos estados do Ceará, Paraíba, Pernambuco, Bahia, Mato Grosso, Minas Gerais, Rio de Janeiro, São Paulo, Paraná, Santa Catarina e Rio Grande do Sul (Barbosa-Fevereiro 1977, Miotto 1987).

Habita campos graminosos ou arbustivos, matas arbustivas, beira de matas de galeria, restingas, cerrados, caatingas, lugares úmidos ou secos, em solos argilosos ou arenosos (Miotto 1987). Na EPTEA, foi coletada em áreas bastante perturbadas, como a margem da estrada para o Centro de Educação Ambiental e o aceiro.

É uma espécie muito variável quanto à forma dos folíolos (Miotto 1987).

Crotalaria L., Sp. Pl. 2: 714. 1753.

Ervas ou subarbustos. Folhas simples, 1-3(-57)-folioladas, pecioladas, raque ausente; estípulas persistentes ou caducas; alas internodaispresentes em algumas espécies. Inflorescências racemosas, terminais, axilares ou opositifólias; brácteas e bractéolas persistentes ou caducas; cálice tubuloso ou campanulado, 5-laciniado, lacínios superiores 2, unidos quase até o ápice ou livres, lacínios inferiores 3 , semelhantes no tamanho; corola, amarela; estames 10, monadelfos, anteras dimorfas, alternando 5 longas basifixas e 5 menores dorsifixas; ovário séssil ou estipitado; estilete geniculado ou curvo, glabro ou barbado; estigma terminal. Fruto legume, cilíndrico, inflado, polispérmico, deiscência geralmente elástica. Sementes orbiculares ou reniformes.

Chave para as espécies de Crotalaria ocorrentes na Mata do Paraíso

1. Folhas simples; alas internodais nos ramos

2. Alas internodais 3-6 mm larg., com ápice reto, 3-7 mm compr.; inflorescências axilares ou terminais C. breviflora

2. Alas internodais $7-12 \mathrm{~mm}$ larg., com ápice falcado, 10-25 mm compr.; inflorescências opositifólias C. stipularia

1. Folhas 3-folioladas; estípulas filiformes ou caducas; alas internodais ausentes

3. Folíolos obovados; cálice 9-13 mm compr., com lacínios iguais medindo ca. $9 \mathrm{~mm}$ compr. C. incana

3. Folíolos linear-lanceolados; cálice ca. $3 \mathrm{~mm}$ compr., com lacínios reduzidos medindo ca. $1 \mathrm{~mm}$ compr. C. lanceolata
Figuras 2A-B

Subarbusto ca. 1,5 m alt.; ramos cilíndricos, vilosos ou tomentosos. Folhas simples, 5,5-10 × 2,5$4,5 \mathrm{~cm}$, ovais, elípticas a lanceoladas, cartáceas, ambas as faces seríceas; alas internodais estreitas, ápice 3-7 mm compr.; estípulas ausentes; pecíolo 2-3 cm compr. Inflorescências multifloras, opositifólias ou terminais; pedúnculo 6-9 cm compr.; raque 8-32 cm compr.; cálice 11-15 mm compr., seríceo externamente, lacínios subiguais, 7-8 mm compr., superiores livres; corola amarela, vexilo 11-13 mm compr., alas 9-13 mm compr., pétalas da carena 11-15 mm compr.; estames 8-11 mm compr.; gineceu estipitado, estípite 1-2 mm compr., ovário ca. $7 \mathrm{~mm}$ compr., glabrescente, 


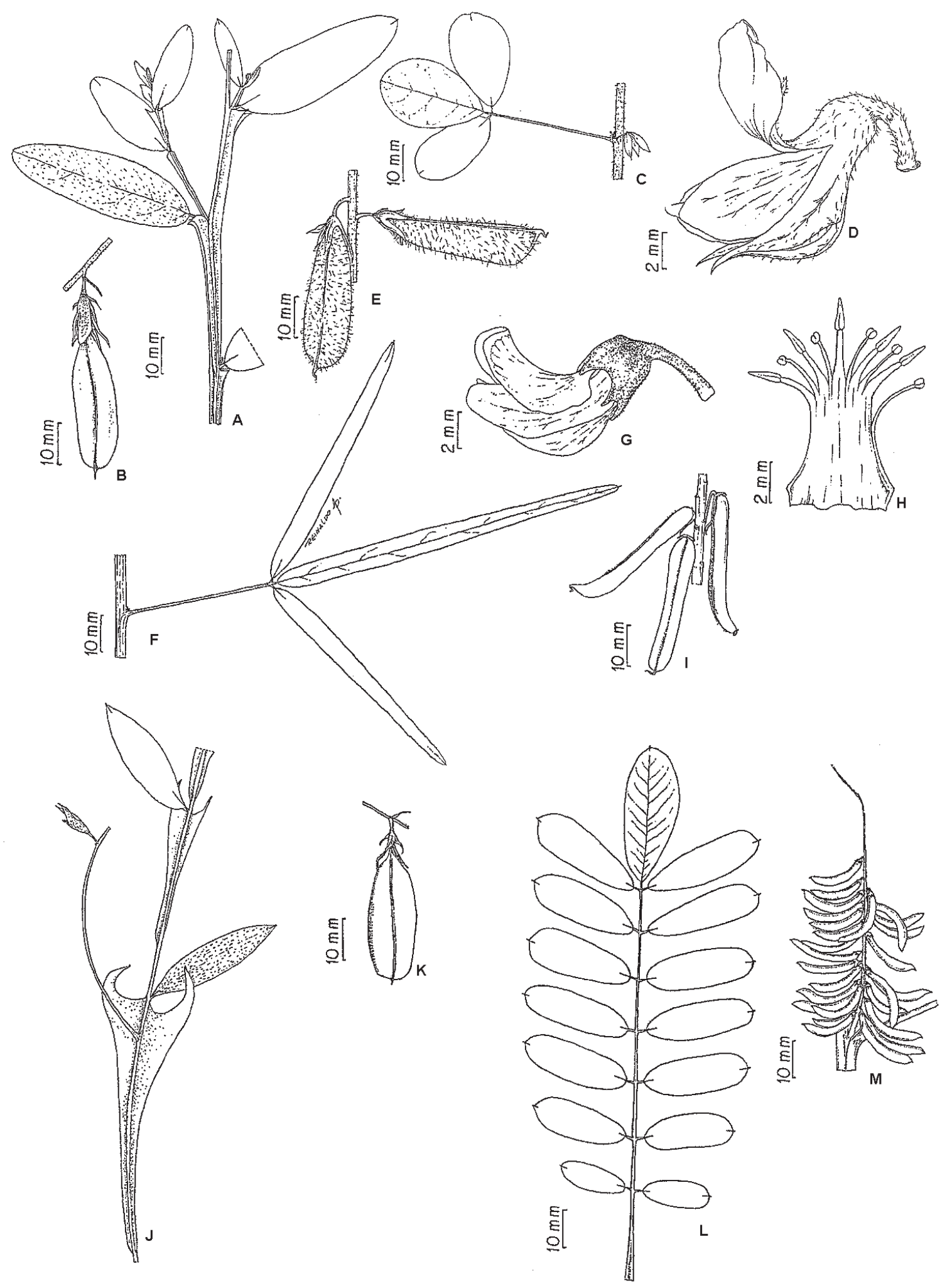

Figura 2. Espéces de Crotalaria e Indigofera da Mata do Paraíso. A-B. Crotalaria breviflora. A. Ramo com alas internodais e folhas. B. Fruto (Eiterer et al. VIC 28.824 e Garcia et al. 1049). C-E. Crotalaria incana. C. Folha. D. Flor. E. Fruto (Garcia \& Padron 966). F-I. Crotalaria lanceolata. F. Folha. G. Flor. H. Estames monadelfos. I. Frutos (Rodrigues \& Basílio 32). J-K. Crotalaria stipularia. J. Ramo com alas internodais, folhas e inflorescência. K. Fruto (Rodrigues \& Basílio 33). L-M. Indigofera suffruticosa. L. Folha. M. Frutos (Rodrigues \& Basílio 13) 
estilete 7-8 mm compr., curvo, ciliado na margem superior ou glabro, estigma capitado, barbado. Fruto 30-40 mm compr., glabro, negro; sementes 17-25, ca. $3 \mathrm{~mm}$ compr., reniformes, castanho-escuras.

Material examinado: BRASIL. Minas Gerais: Viçosa, EPTEA, Estrada para o Centro de Educação Ambiental, 24-VIII-2001, F.C.P. Garcia \& I.M. Corrêa 848 (VIC); idem, 17-I-2002, F.C.P. Garcia \& P. Padron 945 (VIC); idem, 28-III-2002, F.C.P. Garcia \& P. Padron 960 (VIC); idem, 28-III-2002, F.C.P. Garcia \& P. Padron 965 (VIC); idem, 4-II-2004, M. Eiterer et al. s.n. (VIC 28824); idem, 13-III-2004, F.C.P. Garcia et al. 1049 (VIC); idem, 17-IV-2004, F.C.P. Garcia et al. 1053 (VIC); idem, 24-I-2005, I.M.C. Rodrigues \& S.C. Ferreira 21 (VIC).

Distribuição restrita à América do Sul, ocorrendo, no Brasil, nos estados da Paraíba, Bahia, Mato Grosso, Goiás, Distrito Federal, Minas Gerais, Rio de Janeiro, São Paulo e Paraná (Filliettaz 2002, Flores 2004). Habita campo rupestre, cerrado, campo sujo, campo de altitude, borda de mata mesófila e de Mata Atlântica, mata secundária de encosta, mata de galeria, mata pluvial tropical e brejo (Filliettaz 2002, Flores 2004). Na EPTEA, C. breviflora foi encontrada em abundância na trilha principal, no aceiro e ao redor do Centro de Educação Ambiental em áreas alteradas.

Esta espécie e C. stipularia, podem ser diferenciadas das outras espécies de Papilionoideae da Estação por apresentarem folhas simples e alas internodais.

2. Crotalaria incana L., Sp. Pl. 2: 716. 1753.

Figuras 2C-E

Subarbusto ca. 1,1 m alt.; ramos cilíndricos, tomentosos. Folhas digitado-3-folioladas; estípulas 4-7 mm compr., filiformes; pecíolo 2-5 cm compr.; folíolos laterais $2-3,5 \times 0,9-2,1 \mathrm{~cm}$, obovados, simétricos, herbáceos, discolores, face adaxial glabra, face abaxial glabrescente. Inflorescências multifloras, terminais; pedúnculo 3-8 cm compr.; raque 4-9,5 cm compr.; cálice 9-13 mm compr., puberulento externamente, lacínios iguais entre si, ca. $9 \mathrm{~mm}$ compr., os superiores livres; corola amarela, vexilo 10$13 \mathrm{~mm}$ compr., alas 9-12 mm compr., pétalas da carena 12-13 mm compr.; estames 11-12 mm compr.; ovário ca. $6 \mathrm{~mm}$ compr., séssil, tomentoso; estilete ca. $8 \mathrm{~mm}$ compr., curvo, ciliado na margem superior; estigma capitado, barbado. Fruto 28-35 mm compr., hirsuto ou tomentoso, verde ou castanho-amarelado; sementes ca. 36 , ca. $3 \mathrm{~mm}$ compr., reniformes, castanhas.

Material examinado: BRASIL. MinAs GERAIS: Viçosa, EPTEA, Aceiro, 28-III-2002, F.C.P. Garcia \& P. Padron 966 (VIC); idem, "Caminho das Águas", 16III-2005, I.M.C. Rodrigues \& L.A. Basílio 31 (VIC).

Possui distribuição pantropical (Polhill 1982), nativa dos trópicos do Novo Mundo, mas ocorrendo também na Ásia e África (Flores 2004). No Brasil, possui ampla distribuição, sendo encontrada em solos arenosos, margens de rios e capoeiras, é também abundante em locais perturbados como beiras de estradas (Flores \& Miotto 2001, Flores 2004). Suas sementes são consideradas tóxicas ao gado (Lorenzi 1991). Na EPTEA, ocorre na trilha do aceiro e no "Caminho das Águas", ambas com vegetação bastante alterada.

Dentre as espécies que apresentam folhas digitado3-folioladas, $C$. incana é facilmente diferenciada de C. lanceolata pelo pecíolo maior ou tão longo quanto os folíolos terminais, folíolos geralmente obovados, as flores com cerca de $1 \mathrm{~cm}$ de compr. e os legumes densamente pubescentes (Lewis 1987, Flores \& Miotto 2001).

3. Crotalaria stipularia Desv., J. Bot. Agric. 3: 76. 1814.

Figuras 2J-K

Subarbustos ca. $60 \mathrm{~cm}$ alt.; ramos cilíndricos, seríceos. Folhas simples, sésseis, 2,5-5 × 1-2 cm, elípticas, cartáceas, face adaxial serícea, face abaxial densamente serícea; alas internodais tornandose mais largas no ápice, ápice 10-17 mm compr., falcado; estípulas ausentes. Inflorescências 1-6floras, opositifólias; pedúnculo 1,3-7,5 cm compr.; raque 0,1-2 cm compr.; cálice 8,5-10 mm compr., tomentoso externamente, lacínios iguais entre si, 7-8 mm compr., os superiores levemente unidos; corola amarela, vexilo, alas e pétalas da carena ca. 7 mm compr.; estames ca. 6 mm compr.; ovário séssil, 3-4 mm compr., glabro ou puberulento, estilete ca. $5 \mathrm{~mm}$ compr., curvo, ciliado na margem superior, estigma capitado, barbado. Fruto ca. $30 \mathrm{~mm}$ compr., glabro; sementes ca. 33, 2-3 mm compr., reniformes, castanho-claras ou avermelhadas.

Material examinado: BRASIL. MinAs Gerais: Viçosa, EPTEA, "Caminho das Águas", 16-III-2005, I.M.C. Rodrigues \& L.A. Basílio 33 (VIC). 
Possui ampla distribuição nos neotrópicos. Na América do Sul é encontrada desde a Venezuela e Guiana, até a Argentina (Filliettaz 2002, Flores 2004). No Brasil, distribui-se nos estados do Roraima, Pará, Maranhão, Ceará, Paraíba, Pernambuco, Alagoas, Bahia, Mato Grosso, Goiás, Distrito Federal, Minas Gerais, Espírito Santo, Rio de Janeiro, São Paulo e Mato Grosso do Sul (Filliettaz 2002, Flores 2004). Ocorre desde o nível do mar até altitudes de $875 \mathrm{~m}$, numa grande diversidade de ambientes, mata mesófila, restinga, mata ciliar, cerrado, campos abertos, campos rupestres e em locais arenosos, brejosos e alterados (Filliettaz 2002, Flores 2004). Na EPTEAé encontrada na margem da trilha do "circuito caminhada", no lado oposto ao da lagoa principal da Reserva, em solo arenoso.

Nesta espécie a parte livre das alas internodais é sempre falcada (Flores 2004).
Desmodium Desv., J. Bot. Agric. 1: 122, pl. 5, 1813.

Ervas ou subarbustos. Folhas 1-3(-5)-folioladas, pecioladas, raque presente; estípulas e estipelas persistentes. Inflorescências pseudoracemosas ou paniculadas, terminais ou axilares; brácteas persistentes ou caducas; bractéolas freqüentemente presentes; cálice campanulado, 5-laciniado, lacínios superiores 2, inteiros ou não, lacínios inferiores 3, semelhantes entre si ou, às vezes, o mediano maior que os laterais; corola 5-mera, rósea, violácea, purpúrea ou azulada; estames 10, diadelfos $(9+1)$ ou monadelfos, anteras uniformes; gineceu séssil ou estipitado; estilete curvo; estigma terminal. Fruto lomento, 1-8articulado, artículo indeiscente ou deiscente, com contorno quase circular a linear ou triangular; semente 1 por artículo.

\section{Chave para as espécies de Desmodium ocorrentes na Mata do Paraíso}

1. Folíolos orbiculares a obcordiformes, 0,4-1,4 cm compr. D. adscendens

1. Folíolo ovado, elíptico, lanceolado ou obovado, 1,8-10,5 cm compr.

2. Estípula ca. $2 \mathrm{~mm}$ compr.; inflorescência axilar, pedúnculo $22-34 \mathrm{~cm}$ compr. D. axillare

2. Estípula 4-11 mm compr.; inflorescência geralmente terminal, pedúnculo 1,2-8 cm compr.

3. Folíolo elíptico a obovado; estípulas soldadas quando jovens D. incanum

3. Folíolo ovado a lanceolado; estípulas sempre livres

4. Subarbusto; estípula ca. $4 \mathrm{~mm}$ compr.; inflorescência paniculada D. discolor

4. Erva prostrada; estípula 5-11 mm compr.; inflorescência pseudoracemosa

5. Folíolo lateral simétrico, com mácula glauca acompanhando a nervura central; lomento com sutura superior levemente sinuosa na região do istmo; artículos subtriangulares D. uncinatum

5. Folíolo lateral assimétrico, sem mácula glauca na nervura central; lomento com sutura superior reta; artículos semi-elípticos D. affine

Desmodium adscendens (Sw.) DC., Prodr. 2: 332. 1825.

Figuras 3A-C

Subarbusto prostrado, $17-30 \mathrm{~cm}$ alt.; ramos cilíndricos, pubescentes na base a uncinadopubérulos no ápice. Folhas 3-folioladas; estípulas 5-6 mm compr., triangulares; estipelas ca. $1 \mathrm{~mm}$ compr., filiformes; pecíolo 0,4-1,1 cm compr.; raques $0,1-0,4 \mathrm{~cm}$ compr.; folíolos laterais 0,4 $1,4 \times 0,3-1,1 \mathrm{~cm}$, orbiculares ou obcordiformes, simétricos, subcartáceos, face adaxial pubérula ou glabrescente, face abaxial pubérula. Inflorescências pseudoracemosas, multifloras, terminais; pedúnculo
1,7-3 cm compr.; raque 6-22 cm compr.; cálice ca. $4 \mathrm{~mm}$ compr., puberulento externamente, lacínios subiguais entre si 1-3 mm compr., os superiores unidos até quase o ápice; corola lilás, vexilo 6-7 $\mathrm{mm}$ compr., alas ca. $6 \mathrm{~mm}$ compr., pétalas da carena ca. $7 \mathrm{~mm}$ compr.; estames 5-6 mm compr.; ovário ca. $3 \mathrm{~mm}$ compr., séssil, velutino; estilete ca. 3,5 $\mathrm{mm}$ compr., glabro; estigma capitado, glabro. Fruto 1-4-articulado, 6-16 × 2-3 mm, uncinado-pubérulo, margem superior reta, inferior constricta entre as sementes, artículo indeiscente, quase retangular; sementes 1-4, 3-4 mm compr., oblongo-orbiculares, castanho-esverdeadas. 


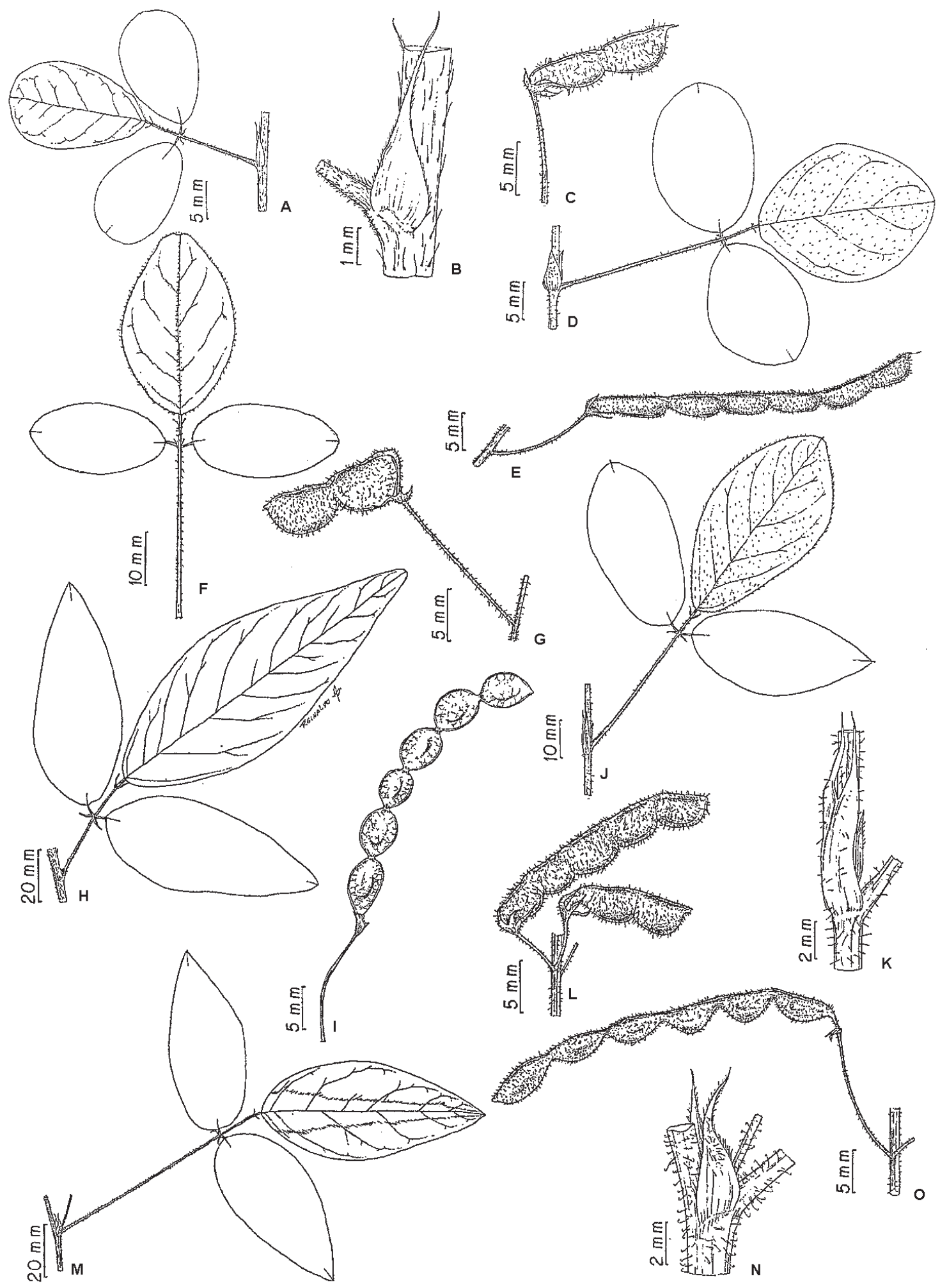

Figura 3. Espécies de Desmodium da Mata do Paraíso. A-C. Desmodium adscendens. A. Folha. B. Estípula. C. Fruto (Rodrigues \& Ferreira 26). D-E. Desmodium afinne. D. Folha. E. Fruto (Rodrigues \& Ferreira 27). F-G. Desmodium axillare. F. Folha. G. Fruto (Rodrigues \& Ferreira 22). H-I. Desmodium discolor. H. Folha. I. Fruto (Rodrigues \& Basílio 39). J-L. Desmodium incanum. J. Folha. K. Estípulas soldadas. L. Fruto (Rodrigues \& Basílio 16). M-O. Desmodium uncinatum. M. Folha. N. Estípula. O. Fruto (Rodrigues 46). 
Material examinado: BRASIL. Minas Gerais: Viçosa, EPTEA, Estrada para o Centro de Educação Ambiental, 21-II-2005, I.M.C. Rodrigues \& S.C. Ferreira 26 (VIC).

Espécie de distribuição pantropical, no Brasil foi encontrada no Amazonas, Pará, Acre, Bahia, Mato Grosso, Minas Gerais, Rio de Janeiro, São Paulo, Paraná, Santa Catarina e Rio Grande do Sul (Azevedo 1981). Ocorre em mata, campo rupestre, pastagem, brejo, restinga, dunas, capoeira, margem de rio e estrada, carrasqueiro, banhado, área disjuntiva de cerrado, floresta de caatinga, até sobre rochas na praia e coleções de água em depressão do terreno (Azevedo 1981). Na EPTEA ocorre frequientemente em áreas bastante perturbadas.

Folíolos orbiculares a obcordiformes são os caracteres diagnósticos para essa espécie, na EPTEA.

Desmodium affine Schltdl., Linnaea 12: 312. 1838.

Figuras 3D-E

Subarbusto prostrado, 20-40 $\mathrm{cm}$ alt.; ramos estriados, uncinado-pubérulos. Folhas 3-folioladas; estípulas 5-10 mm compr., triangulares ou elípticas; estipelas ca. 2 mm compr., filiformes; pecíolo 2,5-3,5 cm compr.; raque 3-10 cm compr.; folíolos laterais 2-4,2 × 1,4-2,3 cm, ovados, assimétricos, cartáceos, face adaxial estrigosa, face abaxial esparso-serícea. Inflorescências pseudoracemosas, multifloras, terminais; pedúnculo 4-6,5 cm compr., raque 8-14 cm compr.; cálice ca. $5 \mathrm{~mm}$ compr., seríceo externamente, lacínios subiguais entre si, 3-3,5 mm compr., os superiores unidos até quase o ápice; corola rosaclara, vexilo 9-10 mm compr., alas 7-8 mm compr., pétalas da carena ca. $7 \mathrm{~mm}$ compr.; estames ca. 8 mm compr.; ovário 7-8 mm compr., séssil, seríceo; estilete ca. $2 \mathrm{~mm}$ compr., glabro; estigma capitado, glabro. Fruto 5-7-articulado, ca. 4 cm compr., uncinado pubérulo, margem superior reta, inferior constricta entre as sementes, artículo indeiscente, semi-elíptico a retangular; sementes 5-7, ca. $2 \mathrm{~mm}$ compr., reniformes, castanhas.

Material examinado: BRASIL. Minas Gerais: Viçosa, EPTEA, Estrada para o Centro de Educação Ambiental, 21-II-2005, I.M.C. Rodrigues \& S.C. Ferreira 27 (VIC).

Distribuição restrita às Américas Central e do Sul. No Brasil, ocorre no Maranhão, Ceará, Bahia, Minas
Gerais, Rio de Janeiro, São Paulo, Paraná, Santa Catarina e Rio Grande do Sul. Habita campo, capoeira, cerrado, capão, pastagem e campo rupestre, mas principalmente matas, preferindo lugares sombrios e úmidos (Azevedo 1981). Na área em estudo, ocorre nas margens das trilhas.

O táxon apresenta semelhança com $D$. axillare nos caracteres reprodutivos e com $D$. incanum e $D$. adscendens nos vegetativos. Distingue-se do primeiro pelas inflorescências terminais, pseudoracemosas e pela presença de 5 a 7 artículos. Diferencia-se de $D$. incanum pela textura serícea da face adaxial dos folíolos, flor rosa-clara e porte da planta, comumente maior. Pode ser separada de D. adscendens pelos folíolos elípticos e seríceos.

Desmodium axillare (Sw.) DC., Prodr. 2: 333. 1825.

Figuras 3F-G

Subarbusto prostrado, $40-60 \mathrm{~cm}$ alt.; ramos estriados, uncinado-pubérulos. Folhas 3-folioladas; estípulas ca. $2 \mathrm{~mm}$ compr., ovado-triangulares; estipelas 1-3 mm compr., setáceas, caducas; pecíolo 2,3-3,4 cm compr.; raque ca. $3 \mathrm{~mm}$ compr.; folíolos laterais 1,7-2,9 × 1,2-1,5 cm, elípticos, assimétricos, herbáceos, discolores, face adaxial glabra, tricomas estrigosos na nervura central, face abaxial esparso-serícea. Inflorescências racemosas, multifloras, axilares, eretas, longas; pedúnculo 2234 cm compr.; raque 4,5-12,5 cm compr.; cálice ca. 2,5 mm compr., pubérulo ou seríceo externamente, esverdeado a roxo, lacínios subiguais entre si, 1-1,5 mm compr., os superiores unidos até quase o ápice; corola rosa-escura, vexilo 4-5 mm compr., alas ca. $4 \mathrm{~mm}$ compr., pétalas da carena 4-5 mm compr.; estames 3-4 mm compr.; gineceu estipitado, estípite ca. $1 \mathrm{~mm}$ compr., ovário ca. $2 \mathrm{~mm}$ compr., seríceo, estilete ca. $2 \mathrm{~mm}$ compr., glabro, estigma capitado, glabro. Fruto longo, estipitado, estípite ca. $3 \mathrm{~mm}$ compr., 1-2-articulado, 6-13 mm compr., uncinadopubérulo, margem superior côncava com entrada na região do istmo, inferior constricta entre as sementes, artículos indeiscentes, subelípticos ou reniformes; sementes 1-2, ca. 4 mm compr., orbicular-reniformes, castanho-esverdeadas.

Material examinado: BRASIL. Minas Gerais: Viçosa, EPTEA, Estrada para o Centro de Educação Ambiental, 24-I-2005, I.M.C. Rodrigues \& S.C. Ferreira 22 (VIC). 
D. axillare está distribuída no Peru, Colômbia, Guiana, Américas Central e do Sul (Bentham 1859). No Brasil, possui ampla distribuição com exceção dos estados do Paraná, Santa Catarina e Rio Grande do Sul (Azevedo 1981). Planta geralmente umbrófila, encontrada em terrenos úmidos, nas matas e em suas margens. Ocasionalmente, ocorre em campo, pastagem e capoeira (Azevedo 1981). Não é freqüente na EPTEA, sendo encontrada apenas na margem da estrada para o Centro de Educação Ambiental.

Pode ser facilmente reconhecida, dentre as outras espécies de Desmodium, na EPTEA, por apresentar hábito prostrado, folhas longo-pecioladas, inflorescências racemosas, axilares e longas e fruto longo e estipitado, com apenas dois artículos.

Desmodium discolor Vogel, Linnaea 12: 103. 1838.

Figuras 3H-I

Subarbusto ereto, ca. 1,7 m alt.; ramos cilíndricos, tomentosos a vilosos. Folhas 3-folioladas; estípulas ca. $4 \mathrm{~mm}$ compr., triangulares, caducas; estipelas 3-8 mm compr., setáceas; pecíolo 0,5-2,1 cm compr.; raque 0,5-3,6 cm compr.; folíolos laterais 3,8-10,5 ×2-4 cm, ovado-lanceolados, herbáceos, discolores, face adaxial esparso-estrigosa a glabrescente, face abaxial vilosa. Inflorescências paniculadas, densifloras, terminais; pedúnculo 1,8-5 cm compr.; raque $16-23 \mathrm{~cm}$ compr.; cálice 3-4 mm compr., seríceo externamente, lacínios subiguais entre si, 1-2 mm compr., os superiores unidos quase inteiramente; corola lilás, tornando-se azulada quando madura, vexilo 6-10 $\mathrm{mm}$ compr., alas 5-10 mm compr., pétalas da carena 6-11 mm compr.; estames 6-9 mm compr.; gineceu estipitado, estípite 1-3 mm compr., ovário 3-4 mm compr., puberulento, estilete 2-4 mm compr., glabro, estigma capitado, glabro. Fruto 25-45 mm compr., 4-7-articulado, glabro, pardacento quando maduro, margens superior e inferior sinuosas, artículos indeiscentes, orbiculares ou elípticos; sementes 4-7, ca. 2 mm compr., orbiculares, castanho-esverdeadas.

Material examinado: BRASIL. Minas Gerais: Viçosa, EPTEA, Estrada para o Centro de Educação Ambiental, 27-II-2002, M.M.M. Lopes et al. 80 (VIC); idem, 18-IV-2005, I.M.C. Rodrigues \& L.A. Basílio 39 (VIC).

Distribui-se na Ásia, África e América do Sul. No Brasil, ocorre nos estados de Goiás, Distrito Federal, Minas Gerais, Rio de Janeiro, São Paulo, Paraná, Santa Catarina e Rio Grande do Sul, sendo cultivada no Acre.
É encontrada em muitos tipos de ambientes, como campos rupestres, cerrados, pastos e matas, sendo muito freqüente na margem de estradas (Azevedo 1981). Na EPTEA ocorre na estrada para o Centro de Educação Ambiental e na trilha principal.

Facilmente reconhecida pelo hábito subarbustivo, alcançando cerca de $2 \mathrm{~m}$ de altura, pelos folíolos grandes, pelas inflorescências densifloras e os artículos orbiculares ou elípticos.

Desmodium incanum DC., Prodr. 2: 332. 1825.

Figuras 3J-L

Subarbusto ereto, $30-40 \mathrm{~cm}$ alt.; ramos cilíndricos, uncinado-pubérulos. Folhas 3-folioladas; estípulas 7-11 mm compr., lanceoladas, soldadas quando jovens; estipelas ca. $5 \mathrm{~mm}$ compr., setáceas; pecíolo 1-4,5 cm compr.; raque 0,2-0,9 cm compr.; folíolos laterais 2-6 × 0,6-2,4 cm, elípticos ou obovados, às vezes lanceolados, simétricos, cartáceos, face adaxial esparso-estrigosa a glabrescente, face abaxial vilosa. Inflorescências pseudoracemosas, multifloras, terminais; pedúnculo 1,2-2,6 cm compr.; raque 2,5$13 \mathrm{~cm}$ compr.; cálice 3-4 mm compr., puberulento externamente, lacínios subiguais entre si, 1-2 mm compr., os superiores unidos até quase o ápice; corola lilás, vexilo 6-7 mm compr., alas 5-6 mm compr., pétalas da carena ca. $6 \mathrm{~mm}$ compr.; estames 5-6 mm compr.; gineceu estipitado, estípite ca. $1 \mathrm{~mm}$ compr., ovário ca. $4 \mathrm{~mm}$ compr., velutino, estilete ca. $1 \mathrm{~mm}$ compr., glabro, estigma capitado, glabro. Fruto 3-6articulado, 15-27 × 2-3 mm, uncinado-pubérulo, margem superior reta, inferior constricta entre as sementes, artículo indeiscente, semi-orbicular a quase quadrado; sementes $3-6$, ca. $3 \times 2 \mathrm{~mm}$, orbicularreniformes, amareladas.

Material examinado: BRASIL. MinAs GERAIS: Viçosa, EPTEA, Arredores do Centro de Educação Ambiental, 5-XI-2004, I.M.C. Rodrigues \& F.C.P. Garcia 9 (VIC); idem, "Caminho das Águas", 26-XI-2004, I.M.C. Rodrigues \& L.A. Basílio 16 (VIC).

Espécie pantropical. No Brasil, é amplamente distribuída de norte a sul, ocorrendo em vários tipos de ambientes, em locais sombreados ou ensolarados (Azevedo 1981). Na EPTEA ocorre nos mais variados ambientes, desde beira de trilhas muito perturbadas até trilhas em regiões em estado avançado de regeneração.

D. incanum apresenta variações morfológicas marcantes, mas pode ser facilmente identificada pelas 
estípulas soldadas, inflorescências terminais e forma retangular do lomento. É próxima principalmente de D. affine, como indicado nos comentários taxonômicos desta espécie.

Desmodium uncinatum (Jacq.) DC., Prodr. 2: 331. 1825.

Figuras 3M-O

Subarbusto prostrado, $50-70 \mathrm{~cm}$ alt.; ramos estriados, uncinado-hirsutos. Folhas 3-folioladas; estípulas 0,6-11 mm compr., triangulares ou lanceoladas, estipelas 1-7 mm compr., filiformes; pecíolo 2,5-7 cm compr.; raque 0,6-1,8 cm compr.; folíolos laterais 3,8-7,5 × 1,4-3,1 cm, ovados ou lanceolados, simétricos, herbáceos ou cartáceos, face adaxial pubérula, estrigosa, face abaxial serícea. Inflorescências pseudoracemosas, multifloras, axilares ou terminais; pedúnculo 1,5-8 cm compr.; raque 3-31 cm compr.; cálice 4-6 mm compr., pubescente externamente, lacínios subiguais entre si, 2-4 mm compr., os superiores unidos até quase o ápice, o mediano pouco maior que os laterais; corola lilás tornando-se azulada quando madura, vexilo 7-11 mm compr., alas 8-10 mm compr., pétalas da carena 9-11 mm compr.; estames 8-11 mm compr.; gineceu estipitado, estípite ca. $1 \mathrm{~mm}$ compr., ovário 5-6 mm compr., seríceo, estilete $2-5 \mathrm{~mm}$ compr., glabro, estigma capitado, glabro. Fruto 5-8 articulado, 35$47 \mathrm{~mm}$ compr., uncinado-hirsuto, margem superior espessada levemente sinuosa na região do ístmo, inferior constricta entre as sementes, artículo indeiscente, subtriangular; sementes $5-8$, ca. $2 \mathrm{~mm}$ compr., reniformes, verdes.

Material examinado: BRASIL. Minas Gerais: Viçosa, EPTEA, Estrada para o Centro de Educação Ambiental, 28-III-2002, F.C.P. Garcia \& P. Padron 963 (VIC); idem, 28-III-2002, F.C.P. Garcia \& P. Padron 964 (VIC); idem, 11-IV-2002, M.M.M. Lopes \& R.M. Carvalho-Okano 85 (VIC); 3-V-2005, I.M.C. Rodrigues 46 (VIC).

Espécie pantropical. No Brasil, ocorre na Bahia, Minas Gerais, Rio de Janeiro, São Paulo, Paraná, Santa Catarina e Rio Grande do Sul, onde habita locais de cerrado, restinga, campo rupestre, mata, pastagem, capoeira, em lugares úmidos como margem de represas ou córregos (Azevedo 1981).

$D$. uncinatum é semelhante a $D$. affine, da qual se diferencia pelos artículos subtriangulares.
Indigofera L., Sp. Pl. 2: 751. 1753.

Ervas ou subarbustos. Folhas imparipinadas, plurifolioladas, raramente 1-folioladas, pecioladas; estípulas e estipelas persistentes; folíolos opostos ou alternos, com tricomas malpiguiáceos. Inflorescências racemosas, axilares ou terminais; brácteas persistentes; bractéolas ausentes; cálice oblíquo a campanulado, 5-laciniado, lacínios superiores e inferiores semelhantes entre si; corola 5-mera, vermelha, rosa, amarela, alaranjada, verde, violácea ou purpúrea; estames 10 , diadelfos $(9+1)$, anteras uniformes, com conectivo apiculado; ovário subséssil; estilete curvo, glabro; estigma terminal. Fruto legume, reto ou curvado, polispérmico, glabrescente, cilíndrico.

Indigofera suffruticosa Mill., Gard. Dict. ed. $8 \mathrm{n}^{\circ}$ 2. 1768 .

Figuras 2L-M

Subarbusto 1,4-1,7 m alt.; ramos cilíndricos, seríceos ou puberulentos. Folhas 9-15(-19)-folioladas; estípulas 4-6 mm compr., filiformes; estipelas ca. 1 mm compr., filiformes, vináceas; pecíolo 2-2,8 cm compr.; raque 4,2-11 cm compr.; folíolos 1,9-3,2(-4) $\times 0,8-1,4 \mathrm{~cm}$, elípticos ou obovados, herbáceos, face adaxial glabra, face abaxial esparso-tomentosa com tricomas malpiguiáceos. Inflorescências multifloras; pedúnculo 0,2-0,4 cm compr.; raque 3,6-6,2 cm compr.; cálice ca. 1,5 mm compr., campanulado, seríceo externamente, lacínios 7-8 mm compr.; corola verde e rosa, vexilo 3-5 mm compr., alas 2-4,5 mm compr., pétalas da carena 3-5 $\mathrm{mm}$ compr.; estames 2-3 mm compr.; ovário 2-3 mm compr., glabrescente, estilete 1-2 mm compr., glabro, estigma globoso. Frutos reflexos, numerosos, 15-22 × 2-3 mm, seríceos, castanho-esverdeados; sementes $5-7$, ca. 1,5 mm compr., cubóides, castanhas.

Material de examinado: BRASIL. Minas Gerais: Viçosa, EPTEA, Estrada para o Centro de Educação Ambiental, 5-XI-2004, I.M.C. Rodrigues \& F.C.P. Garcia 8 (VIC); idem, Arredores do Centro de Educação Ambiental, 26-XI-2004, I.M.C. Rodrigues \& L.A. Basílio 13 (VIC).

Amplamente distribuída na América tropical e subtropical, com centro de dispersão no Brasil central ou norte e com limite sul de ocorrência no Uruguai e nordeste da Argentina (Eisinger 1987). No Brasil, ocorre do norte ao sul do país (Moreira \& Tozzi 1997), em vegetação secundária, beira de estradas, terras cultivadas, restinga e caatinga (Lewis 1987). 
Folíolos opostos com face adaxial glabra e abaxial com tricomas malpiguiáceos e frutos numerosos, reflexos são caracteres que a diferenciam de I. truxillensis Kunth, com a qual se assemelha vegetativamente.

Rhynchosia Lour., Fl. Cochinch.: 425, 460. 1790.

Ervas, trepadeiras ou subarbustos. Folhas 3-folioladas ou 1-folioladas, pecioladas, raque presente; estípulas persistentes ou caducas; estipelas caducas. Inflorescências racemosas, axilares, raramente paniculadas; brácteas persistentes ou caducas; bractéolas ausentes; cálice glandular, tubuloso ou campanulado, 5-laciniado, lacínios superiores 2, unidos quase até o ápice, lacínios inferiores 3, desiguais entre si, o mediano maior que os laterais; corola 5-mera, amarela, guias de néctar castanhoavermelhadas freqüentemente presentes; estames 10, diadelfos $(9+1)$, anteras uniformes; ovário séssil ou subséssil; estilete reto; estigma terminal. Fruto legume, deiscente.

Chave para as espécies de Rhynchosia ocorrentes na Mata do Paraíso

1. Estípulas 5-6 mm compr.; folíolos com tricomas glandulares em ambas as faces; frutos com margens inteiras, tricomas glandulares presentes R. edulis

1. Estípulas 3-4 mm compr.; folíolos com tricomas glandulares somente na face abaxial; frutos com margens constrictas entre as sementes, tricomas glandulares ausentes R. minima

1. Rhynchosia edulis Griseb., Abh. Konigl. Ges. Wiss. Göttingen. 19: 123. 1874.

Figuras 4A-D

Trepadeira; ramos cilíndricos, tomentosos com tricomas glandulares. Folhas 3-folioladas; estípulas 5-6 mm compr., lanceoladas; estipelas ca. $2 \mathrm{~mm}$ compr., setáceas; pecíolo 1,6-5,1 cm compr.; raque 0,6-1,6 cm compr.; folíolos laterais 2-4,4 × 1,3-3,7 $\mathrm{cm}$, ovados ou trulados, assimétricos, cartáceos, face adaxial pubescente com muitos pêlos ao longo das nervuras principal e secundárias, face abaxial vilosa, ambas as faces com tricomas glandulares. Inflorescências multifloras; pedúnculo 3,4-7 cm compr.; raque 4,4-6,7 cm compr.; cálice ca. 6 $\mathrm{mm}$ compr., tomentoso com tricomas glandulares externamente, lacínios superiores 2,5-3 mm compr., os laterais ca. $3 \mathrm{~mm}$ compr., o mediano ca. 4,5 mm compr.; corola amarela com guias de néctar vermelhas, vexilo ca. $11 \mathrm{~mm}$ compr., externamente piloso com tricomas glandulares, alas $9-10 \mathrm{~mm}$ compr., pétalas da carena ca. $10 \mathrm{~mm}$ compr.; estames (5-)7-10 mm compr.; ovário ca. $3 \mathrm{~mm}$ compr., tomentoso, com pêlos glandulares, estilete 6-7 mm compr., seríceo na base e glabro no ápice, estigma capitado, glabro. Fruto $16 \times 5-6 \mathrm{~mm}$, viloso com tricomas glandulares externamente, margens inteiras, verde rajado; sementes 2 , ca. $4 \times 3 \mathrm{~mm}$, orbiculares, castanhas com pontos pretos.

Material examinado: BRASIL. MinAS GERAIS: Viçosa, EPTEA, Aceiro, 23-II-2005, I.M.C. Rodrigues et al. 29 (VIC).

Pode ser encontrada na América Central, América do Norte e América do Sul, onde ocorre na Argentina, Bolívia, Brasil, Colômbia, Paraguai, Peru e Venezuela (ILDIS 2007).

Esta espécie é distinta de $R$. minima, a outra espécie do gênero encontrada na EPTEA, pelas sementes castanhas com pontos pretos, além dos caracteres de chave.

Rhynchosia minima (L.) DC., Prodr. 2: 385. 1825.

Figuras 4E-G

Trepadeira; ramos estriados, tomentosos. Folhas 3-folioladas; estípulas 3-4 mm compr., lanceoladas, caducas; estipelas caducas; pecíolo 2-4 cm compr.; raque 1,3-1,5 cm compr.; folíolos laterais 3,6-7 $\times$ 2,3-4,4 cm, ovados, assimétricos, subcartáceos ou cartáceos, face adaxial vilosa, face abaxial densovilosa com tricomas glandulares. Inflorescências multifloras, axilares, eretas; pedúnculo ca. $1,7 \mathrm{~cm}$ compr.; raque 7-10 cm compr.; cálice 3-5 mm compr., tomentoso com tricomas glandulares, externamente, lacínios superiores 1-1,5 mm compr., os laterais 2-2,5 mm compr., o mediano 2,5-3 mm compr.; corola amarela, vexilo 8-9 mm compr., externamente seríceo com tricomas glandulares, alas e pétalas da carena 7-8 mm compr.; estames 6-8 mm compr.; ovário 2-3 mm compr., tomentoso com pêlos glandulares, estilete 5-6 mm compr., seríceo na base a glabro no ápice, estigma capitado, glabro. Fruto 10-20 × 7-10 mm, tomentoso, tricomas glandulares ausentes, margens constrictas entre as sementes, esverdeado a acinzentado; sementes 2 , ca. $4 \times 2 \mathrm{~mm}$, oblongo-reniformes, vermelhas e amarelas. 


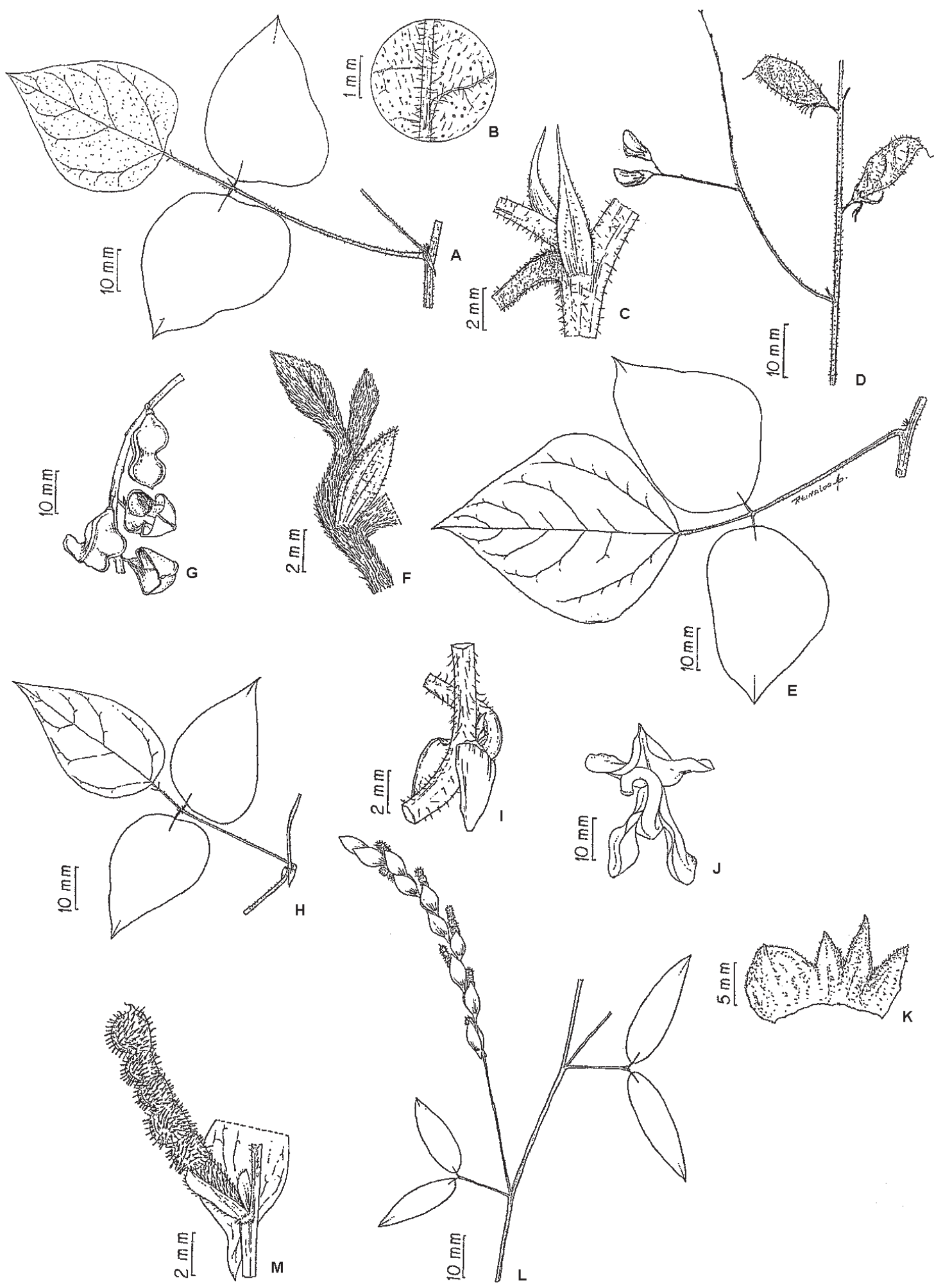

Figura 4. Espécies de Rhynchosia, Vigna e Zornia da Mata do Paraíso. A-D. Rhynchosia edulis. A. Folha. B. Detalhe dos tricomas glandulares. C. Estípulas. D. Ramo com inflorescência e frutos (Rodrigues et al. 29). E-G. Rhynchosia minima. E. Folha. F. Estípulas. G. Frutos (Carvalho-Okano et al. 14.695 e Rodrigues \& Basílio 11). H-K. Vigna candida. H. Folha. I. Estípulas com aurículas. J. Flor. K. Cálice (Rodrigues et al. 58). L-M. Zornia gemella. L. Ramo com folhas, inflorescência espiciforme com frutos. M. Detalhe do fruto (Rodrigues et al. 28). 
Material examinado: BRASIL. MinAS GeRAIS: Viçosa, EPTEA, Aceiro, 23-VIII-1995, R.M. Carvalho-Okano et al. s.n. (VIC14695); idem, 12-XI-2004, I.M.C. Rodrigues \& L.A. Basílio 11 (VIC).

Esta espécie é pantropical, encontrada na África, Ásia, Austrália, Caribe, Índia, Ilhas do Oceano Pacífico, América do Norte, América Central e América do Sul, onde ocorre na Argentina, Bolívia, Brasil, Chile, Colômbia, Equador, Guiana Francesa, Guiana, Paraguai, Peru, Suriname e Venezuela (ILDIS 2007).

Vigna Savi, Nuovo Giorn. Lett. 8: 113. 1824.

Trepadeiras ou subarbustos. Folhas 3-folioladas, pecioladas, raque presente; estípulas prolongadas ou não abaixo das inserções, persistentes; estipelas persistentes. Inflorescências pseudoracemosas, axilares; brácteas e bractéolas persistentes ou caducas; cálice tubuloso ou campanulado, 4-5laciniado, lacínios superiores 1-2, inteiros, lacínios inferiores 3, semelhantes ou desiguais entre si, sendo o mediano geralmente maior que os laterais; corola 5-mera, amarelo-arroxeada ou branca, ressupinada; vexilo caloso ou não na base, pétalas da carena retas, espiraladas ou lateralmente torcidas, soldadas dorsalmente; estames 10, diadelfos $(9+1)$, anteras uniformes; ovário séssil; estilete reto, curvo ou espiralado, levemente achatado, espessado apicalmente, barbado, estigma terminal ou lateral. Fruto legume, reto ou curvado, liso, plano, polispérmico; sementes reniformes.

Vigna candida (Vell.) Maréchal, Mascherpa \& Stainier, Taxon 27(2-3): 201. 1978.

Figuras $4 \mathrm{H}-\mathrm{K}$

Trepadeira; ramos cilíndricos, puberulentos. Estípulas 3-5 mm compr., triangulares, auriculadas, aurículas ca. $2 \mathrm{~mm}$ compr.; estipelas 1-2 mm compr., elípticas; pecíolo 2,3-3,6 cm compr.; raque ca. 0,6 cm compr.; folíolos laterais 2,5-3,7 × 1,7$2,5 \mathrm{~cm}$, ovados, assimétricos, subcartáceos, ambas as faces pubescentes. Inflorescências 1-3-floras; pedúnculo 2,5-7 cm compr.; raque 0,6-2,2 cm compr.; cálice campanulado, 7-9 mm compr., pubescente externamente, lacínios 4, subiguais entre si, o superior 4-5 mm compr., os laterais 3-4 mm compr., o mediano 5-6 mm compr.; corola branca, com guias de néctar violáceas, vexilo ca. $34 \mathrm{~mm}$ compr., alas ca. $34 \mathrm{~mm}$ compr., pétalas da carena $36-40 \mathrm{~mm}$ compr., torcidas lateralmente; estames 38-40 mm compr.; ovário ca.
14 mm compr., séssil, tomentoso, estilete ca. $34 \mathrm{~mm}$ compr., espiralado, glabro a densamente barbado no ápice, estigma afunilado, barbado. Fruto não observado.

Material examinado: BRASIL. MinAs Gerais: Viçosa, EPTEA, Aceiro, 6-VI-2005, I.M.C. Rodrigues et al. 58 (VIC).

Distribui-se pelo México, Colômbia, Paraguai e Brasil (Maréchal et al. 1978, ILDIS 2007).

É diferenciada das outras espécies de Papilionodeae da EPTEA por apresentar pétalas da carena torcidas lateralmente, corola branca com guias de néctar violáceas e folíolos herbáceos. A forma dos folíolos é variável, geralmente ovada a lanceolada (Maréchal et al. 1978).

Zornia J.F. Gmel., Syst. Nat. 2(2): 1076. 1791.

Ervas ou subarbustos. Folhas paripinadas, 2 ou 4-folioladas, pecioladas ou sésseis; estípulas auriculadas, persistentes; estipelas ausentes. Inflorescências espiciformes, axilares, raramente terminais; brácteas ausentes; bractéolas geralmente semelhantes às estípulas, com ou sem aurícula, geralmente pontuadas, persistentes; cálice tubuloso ou campanulado, 5-laciniado, lacínios superiores unidos quase até o ápice, lacínios inferiores desiguais, sendo o mediano maior que os laterais; corola, geralmente amarela, raro roxa; estames monadelfos, anteras dimorfas; ovário séssil ou subséssil; estilete curvo, glabro; estigma terminal. Lomentos, 2-8(15)-articulados, aculeados ou não, pontuados ou não, indumentados ou não. Sementes orbiculares ou reniformes.

Zornia gemella (Willd.) Vogel, Linnaea 12: 61. 1838.

Figuras 4L-M

Subarbusto às vezes prostrado, $30-50 \mathrm{~cm}$ alt.; ramo cilíndrico, glabrescente. Folhas 2-folioladas; estípulas 5-11 mm compr., lanceoladas; pecíolo ca. $0,1 \mathrm{~cm}$ compr.; raque ausente; folíolos inferiores 1-1,7 $\times$ 0,6-0,9 cm, elípticos ou obovados, assimétricos, subcartáceos, face adaxial glabra, face abaxial pubérula, folíolos superiores 1,5-2,7(-2,9) × 0,4-0,8 $\mathrm{cm}$, lanceolados, simétricos, subcartáceos, ambas as faces glabras. Inflorescências multifloras, congestas; pedúnculo 1-4,1 cm compr.; raque 4-8,3 cm compr.; bráctéolas 7-10 × 3-4 mm, elípticas, curvas, com 5 nervuras, aurícula ca. $1 \mathrm{~mm}$ compr.; cálice ca. $3 \mathrm{~mm}$ 
compr., pubescente externamente, lacínios superiores e mediano ca. $2 \mathrm{~mm}$ compr., os laterais $0,5-1 \mathrm{~mm}$ compr.; corola amarela, com guias de néctar vermelhas, vexilo 7-8 mm compr., alas 6-7 mm compr., pétalas da carena ca. $8 \mathrm{~mm}$ compr.; estames ca. $8 \mathrm{~mm}$ compr.; ovário ca. $2 \mathrm{~mm}$ compr., seríceo, estilete 5-6 mm compr., glabro, estigma truncado, glabro. Fruto 5-7-articulado, 8-13 mm compr., reticulado, piloso com acúleos recobertos por pêlos retrorsos; sementes 5-7, ca. 1-1 mm diâm., circulares, verdes, pontuadas de negro.

Material examinado: BRASIL. Minas GeRAIs: Viçosa, EPTEA, Arredores do Centro de Educação Ambiental, 26-XI-2004, I.M.C. Rodrigues \& L.A. Basílio 14 (VIC); idem, Aceiro, 23-II-2005, I.M.C. Rodrigues et al. 28 (VIC).

Freqüente no norte da Argentina e Brasil, onde ocorre na Bahia, Minas Gerais, São Paulo, Rio de Janeiro e Rio Grande do Sul, crescendo preferencialmente em campos limpos ou áreas onde haja uma perturbação antropizadas (Mohlenbrock 1961, Sciamarelli \& Tozzi 1996).

Os caracteres diagnósticos da espécie são as bractéolas pequenas elípticas a ovais, expondo os frutos, e os lomentos longos e geralmente exertos, com artículos reticulados (Mohlenbrock 1961, Sciamarelli \& Tozzi 1996).

O levantamento comprovou a grande representatividade específica de Papilionoideae dentre as espécies herbáceo-subarbustivas da Mata do Paraíso. As espécies mais freqüentes foram Desmodium incanum e Crotalaria breviflora, sendo encontradas às margens da maioria das trilhas percorridas, principalmente em locais perturbados. De Centrosema dasyanthum foi observado apenas um indivíduo na Reserva, encontrado na trilha do aceiro. Crotalaria incana, Crotalaria lanceolata, Desmodium adscendens, Indigofera suffruticosa e Zornia gemella podem ser consideradas invasoras. Neste estudo, ainda foram levantadas duas espécies introduzidas, Neonotonia wightii e C. lanceolata.

\section{Agradecimentos}

As autoras agradecem ao $\mathrm{CNPq}$ pela bolsa de Iniciação Científica concedida, ao Departamento de Engenharia Florestal da Universidade Federal de Viçosa pela autorização de coletas, aos funcionários Luiz A. Basílio e Joel Stanciolla pelo auxílio nos trabalhos de campo e ao Reinaldo A. Pinto pelas ilustrações.

\section{Literatura citada}

Azevedo, A.M.G. 1981. O gênero Desmodium Desv. no Brasil - considerações taxonômicas. Dissertação de Mestrado, Universidade Estadual de Campinas, Campinas.

Barroso, G.M., Peixoto, A.L., Costa, C.G., Ichasso, C.L.F., Guimarães, E.F. \& Lima, H.C. 1991. Sistemática das Angiospermas do Brasil, v.2. Imprensa Universitária, Viçosa.

Barroso, G.M., Morim, M.P., Peixoto, A.L. \& Ichasso, C.L.F. 1999. Frutos e sementes: morfologia aplicada à sistemática de dicotiledôneas. Imprensa Universitária, Viçosa.

Barbosa-Fevereiro, V.P. 1977. Centrosema (A.P. De Candolle) Benthan do Brasil - Leguminosae-Faboideae. Rodriguésia 42: 159-217.

Bentham, G. 1859. Papilionaceae. Leguminosae: Desmodium. In: C.F.P. Martius, S. Endlicher \& I. Urban (ed.). Flora Brasiliensis. Typographia Regia, Monachii, v. 15, pp. 94-106.

Brandão, M. 1992. Gênero Aeschynomene L.: espécies mineiras e sua distribuição no país. Daphne 2: 27-46.

Braz, D.M., Vieira, M.F. \& Carvalho-Okano, R.M. 2000. Aspectos reprodutivos de espécies de Acanthaceae Juss. de um fragmento de floresta do município de Viçosa, Minas Gerais. Revista Ceres 47: 229-239.

Brummitt, R.K. \& Powell, C.E. 1992. Authors of plant names. Royal Botanic Gardens, Kew.

Castro, P.S. 1980. Influência da cobertura florestal na qualidade da água em duas bacias hidrográficas da região de Viçosa, MG. Dissertação de Mestrado, Escola Superior de Agricultura de Luiz de Queiroz, Piracicaba.

Chappill, J.A. 1995. Cladistic analyses of the Leguminosae: the development of an explicit hypothesis. In: M.D. Crisp \& J.J. Doyle (eds.). Advance in Legume Systematics: Phylogeny. Royal Botanic Gardens, Kew, v.7, pp. 1-9.

Drummond, G.M., Martins, C.S., Machado, A.B.M., Sebaio, F.A. \& Antonini, Y. 2005. Biodiversidade em Minas Gerais: um atlas para sua conservação. Fundação Biodiversitas, Belo Horizonte.

Eisinger, S.M. 1987. O gênero Indigofera L. (LeguminosaePapilionoideae-Indigoferae) no Rio Grande do Sul. Acta Botanica Brasilica 1: 123-40.

Fernandes, A. 1996. O táxon Aeschynomene no Brasil. Editora Universidade Federal do Ceará, Fortaleza.

Fidalgo, O. \& Bononi, V.L.R. 1989. Técnicas de coleta, preservação e herborização de material botânico. Instituto de Botânica, São Paulo.

Filliettaz, A.M. 2002. Estudos taxonômicos de espécies de Crotalaria sect. Calycinae Wight \& Arn. (LeguminosaePapilionoideae- Crotalarieae) no Brasil. Dissertação de Mestrado, Universidade Estadual de Campinas, Campinas. 
Flores, A.S. 2004. Taxonomia, números cromossômicos e química de espécies de Crotalaria L. (LeguminosaePapilionoideae) no Brasil. Tese de Doutorado, Universidade Estadual de Campinas, Campinas.

Flores, A.S. \& Miotto, S.T.S. 2001. Gênero Crotalaria L. (Leguminosae-Faboideae) na Região Sul do Brasil. Iheringia, série Botânica 55: 189-247.

Guedes-Bruni, R.R., Morim, M.P., Lima, H.C. \& Sylvestre, L.S. 2002. Inventário florístico. In: L.S. Sylvestre \& M.M.T. Rosa (eds.). Manual metodológico para estudos botânicos na Mata Atlântica. Universidade Federal Rural do Rio de Janeiro, Seropédica, pp. 2449.

ILDIS. 2007. International Legume Database and Information Service. http://www.ildis.org. (acesso em 20/06/2007).

Leal Filho, N. 1992. Caracterização do banco de sementes de três estádios de uma sucesssão vegetal na Zona da Mata de Minas Gerais. Dissertação de Mestrado, Universidade Federal de Viçosa, Viçosa.

Lessa, G., Gonçalves, P.R., Morais Júnior., M.M., Costa, F.M., Pereira, R.F. \& Paglia, A.P. 1999. Caracterização e monitoramento da fauna de pequenos mamíferos terrestres de um fragmento de mata secundária em Viçosa, Minas Gerais. Revista Bios 7: 41-49.

Lewis, G.P. 1987. Legumes of Bahia. Royal Botanic Gardens, Kew.

Lewis, G.P., Schrire, B., Mackinder, B. \& Lock, M. 2005. Legumes of the world. Royal Botanical Gardens, Kew.

Lorenzi, H. 1991. Plantas daninhas do Brasil. 2 ed. Plantarum, Nova Odessa.

Maréchal, R., Mascherpa, J.M. \& Stainer, F. 1978. Éstude taxonomique d'um groupe complex d'espéces des genres Phaseolus et Vigna (Papilionaceae) sur la base de données morphologiques et polliniques, traitées par l'analyse informatique. Boissiera 28: 1-273.

Meira Neto, J.A.A. \& Martins, F.R. 2000. Composição florística do estrato herbáceo-arbustivo de uma floresta estacional semidecidual em Viçosa-MG. Revista Árvore 24: 407-416.

Meira Neto, J.A.A. \& Martins, F.R. 2002. Composição florística de uma floresta estacional semidecidual Montana no município de Viçosa-MG. Revista Árvore 26: 437-446.

Miotto, S.T.S. 1987. Os gêneros Centrosema (DC.) Benth. e Clitoria L. (Leguminosae, Faboideae) no Rio Grande do Sul. Iheringia, série Botânica 36: 15-39.

Mohlenbrock, R.H. 1961. Amonograph of the Leguminosae genus Zornia. Webbia 16: 1-141.
Moreira, J.L. \& Tozzi, A.M.G.A. 1997. Indigofera L. (Leguminosae, Papilionoideae) no estado de São Paulo, Brasil. Revista Brasileira de Botânica 20: 97-117.

Polhill, R.M. 1982. Crotalaria in África Madagascar. Royal Botanic Gardens, Kew.

Polhill, R.M. \& Raven, P.H. 1981. Advances in Legume Systematics part I and II. Royal Botanic Gardens, Kew.

Radford, A.E., Dickison, W.C., Massey, J.R. \& Bell, C.R. 1974. Vascular plant systematics. Harper \& Row, New York.

Rizzini, C.T. 1992. Tratado de fitogeografia do Brasil: aspectos ecológicos, sociológicos e florísticos. Âmbito Cultural, São Paulo.

Rodrigues, I.M.C. \& Garcia, F.C.P. 2007. Papilionoideae (Leguminosae) arbóreas e lianas na Estação de Pesquisa, Treinamento e Educação Ambiental (EPTEA), Mata do Paraíso, Viçosa, Zona da Mata mineira. Revista Árvore 31: 521-532.

Rudd, V.E. 1955. The American species of Aeschynomene. Contribution from the National Herbarium 32: 1-172.

Sciamarelli, A. \& Tozzi, A.M.G.A. 1996. Zornia J.F. Gmel. (Leguminosae-Papilionoideae-Aeschynomeneae) no estado de São Paulo. Acta Botanica Brasilica 10: 237 266.

Silva, A.F., Fontes, N.R.L. \& Leitão Filho, H.F. 2000. Composição florística e estrutura horizontal do estrato arbóreo de um trecho da Mata da Biologia da Universidade Federal de Viçosa- Zona da Mata de Minas Gerais. Revista Árvore 24: 397-405.

Silva, A.F., Oliveira, R.V., Fontes, N.R.L. \& Paula, A. 2003. Composição florística e grupos ecológicos das espécies de um trecho de floresta semidecídua submontana da Fazenda São Geraldo, Viçosa- MG. Revista Árvore 27: 311-319.

Sprent, J. I. 2001. Nodulation in legumes. Royal Botanic Gardens, Kew.

Veloso, H.P., Rangel Filho, A.L.R. \& Lima, J.C.A. 1991. Classificação da vegetação brasileira, adaptação a um sistema Universal. Fundação Instituto Brasileiro de Geografia e Estatística, Rio de Janeiro.

Volpato, M.M.L. 1994. Regeneração natural em uma floresta secundária no domínio da Mata Atlântica: uma análise fitossociológica. Dissertação de Mestrado, Universidade Federal de Viçosa, Viçosa.

Wojciechowski, M.F. 2003. Recontructing the phylogeny of legumes (Leguminosae): an early 21 st century perspective. In: B.B. Klitgaard \& A. Bruneau (eds.). Advances in Legume Systematics. Royal Botanic Gardens, Kew, v. 10, pp. 5-35. 